\title{
An Anti-inflammatory Peptide Isolated from Seahorse Hippocampus kuda bleeler Inhibits the Invasive Potential of MG-63 Osteosarcoma Cells
}

\author{
Yun Ji Yang, Se-Kwon Kim and Sun Joo Park* \\ Department of Chemistry, Pukyong National University, Busan 608-737, Korea
}

\begin{abstract}
Osteosarcoma is the most common primary malignancy of bone, and patients often develop pulmonary metastasis. The mechanisms underlying osteosarcoma metastasis remain to be elucidated. Recently, anti-inflammatory agents were shown to be useful in the treatment of tumor progression. We previously isolated a natural anti-inflammatory peptide from the seahorse Hippocampus kuda bleeler. Here, we examined the antitumor metastatic activity of this peptide and investigated its mechanism. The peptide significantly inhibited 12-O-tetradecanoylphorbol-13-acetate (TPA)-induced invasive migration of human osteosarcoma MG-63 cells. Its inhibitory effect on invasive migration was associated with reduced expression of matrix metalloproteinases (MMP1 and MMP2). In addition, TPA stimulation increased intracellular reactive oxygen species (ROS) generation and small GTPase Rac1 expression, whereas the peptide decreased ROS generation and Rac1 activation. Taken together, these results suggest that the peptide inhibits invasive migration of MG-63 osteosarcoma cells by inhibiting MMP1 and MMP2 expression through downregulation of Rac1-ROS signaling.
\end{abstract}

Key words: Hippocampus kuda bleeler, Peptide, Osteosarcoma, Invasion, ROS, MMP

\section{Introduction}

Osteosarcoma is the most common malignant bone cancer in children and adolescents (Thompson et al., 2002; Hauben et al., 2003). Over $80 \%$ of patients with osteosarcoma have metastatic or micrometastatic disease at diagnosis (Mehta et al., 1986; Kaste et al., 1999). For patients presenting with metastatic diseases or tumor recurrence, outcomes are far worse, with survival rates below 30\% (Zhang et al., 2008). Current treatment for osteosarcoma includes chemotherapy and surgery. Unfortunately, major problems associated with chemotherapy persist, in particular, the cytotoxic effects of chemotherapy on normal tissues and organs. Thus, research has focused on the discovery of new agents and strategies to prevent the progression of osteosarcoma.

Our knowledge of the mechanistic control of invasion and metastasis in osteosarcoma is limited. Tumor growth, invasion, and metastasis require tumor cell proliferation, proteolytic digestion of the extracellular matrix (ECM), cell migration through basement membranes into the circulatory system, and extravasation and growth at the metastatic sites (Liotta and Kohn, 2001). Matrix metalloproteinases (MMPs) have been known to contribute to this metastatic process by degrading basement membranes (Arii et al., 1996; Klein et al., 2004). MMPs and their endogenous inhibitors participate in the invasive process of human osteosarcoma (Kähäri and SaarialhoKere, 1999; Kimura et al., 2011). MMPs can also promote tumor growth by increasing the bioavailability of growth factors in the ECM (Chambers and Matrisian, 1997). Recent studies have also suggested that anti-inflammatory agents exert sub-
Open Access http://dx.doi.org/10.5657/FAS.2012.0029

This is an Open Access article distributed under the terms of the Creative Commons Attribution Non-Commercial License (http://creativecommons. org/licenses/by-nc/3.0/) which permits unrestricted non-commercial use, distribution, and reproduction in any medium, provided the original work is properly cited. pISSN: 2234-1749 eISSN: 2234-1757
Received 15 December 2011; Revised 17 January 2012; Accepted 30 January 2012

*Corresponding Author

E-mail: parksj@pknu.ac.kr 
stantial protective effects on tumor promotion and metastasis by blocking the expression of MMPs (Kim et al., 2009). Thus, MMPs play a critical role in cancer and inflammation. In addition, among the molecules involved in inflammation, reactive oxygen species (ROS), such as superoxide and hydrogen peroxide, likely play a role in linking inflammation to carcinogenesis. ROS are well known as key inducers of MMPs and subsequent tumor progression (Mori et al., 2004; Nelson and Melendez, 2004). These findings suggest that downregulation of ROS signals may be an effective tool for the treatment of osteosarcoma. However, the importance of ROS signals on the metastatic property of osteosarcoma cells has not been studied.

A natural peptide from the enzymatic hydrolysates of the seahorse Hippocampus kuda Bleeler was found to inhibit collagen release via its anti-inflammatory effect (Ryu et al., 2010). The peptide suppressed nitric oxide production via downregulation of inducible nitric oxide synthase (iNOS), a well-known inflammatory factor. In the present study, we examined the effect of this peptide on the metastatic potential of MG-63 osteosarcoma cells. The peptide was found to suppress invasive migration of MG-63 osteosarcoma cells by inhibiting the expression of MMPs via downregulation of Rac1-ROS signaling.

\section{Materials and Methods}

\section{Preparation of the anti-inflammatory peptide}

The anti-inflammatory seahorse peptide was prepared as reported by Ryu et al. (2010). To prepare the peptide from seahorse protein, enzymatic hydrolysis using several commercial enzymes (alcalase, neutrase, papain, pepsin, pronase E, and trypsin) was performed. At an enzyme/substrate ratio of $1 / 100(\mathrm{w} / \mathrm{w})$, the reaction mixture was incubated for $8 \mathrm{~h}$ with stirring and then heated in a boiling water bath $\left(100^{\circ} \mathrm{C}\right)$ for $10 \mathrm{~min}$ to inactivate the enzyme. Pronase E-derived seahorse hydrolysates exhibiting the greatest downregulation of collagen release and iNOS were further purified by Hiprep 16/10 DEAE FF anion-exchange chromatography (GE Healthcare, Piscataway, NJ, USA) and reverse-phase high-performance liquid chromatography using a Primesphere $10 \mathrm{C}_{18}(20 \times 250$ $\mathrm{mm}$ ) column. The purity of the peptide was over $99 \%$ according to assessment by reverse phase-high performance liquid chromatography and N-terminal sequence analysis. The amino acid sequence of the purified peptide was determined to be LEDPFDKDDWDNWK by electrospray ionization mass spectrometry spectroscopy.

\section{Cell culture and reagents}

MG-63 human osteosarcoma cells from the American
Type Culture Collection (ATCC, Manassas, VA, USA) were routinely grown in Dulbecco's modified Eagle's medium (DMEM) supplemented with 10\% heat-inactivated fetal bovine serum (FBS; Gibco-BRL Life Technologies, Grand Island, NY, USA), $100 \mathrm{U} / \mathrm{mL}$ penicillin, and $100 \mathrm{mg} / \mathrm{mL}$ streptomycin in $5 \% \mathrm{CO}_{2}$-containing air at $37^{\circ} \mathrm{C}$. For experiments, cells were passaged at least three times and detached with Trypsin-EDTA. Matrigel was obtained from BD Biosciences (San Jose, CA, USA). Antibodies against MMP1, MMP2, Rac1, and actin were obtained from Santa Cruz Biotechnology (Santa Cruz, CA, USA), BD Biosciences, Cell Signaling Technology (Beverly, MA, USA), and Sigma (St. Louis, MO, USA), respectively. Dichlorofluorescein diacetate (DCF-DA) was acquired from Molecular Probes (Eugene, OR, USA). Chemicals and reagents were purchased form Sigma, if not otherwise noted.

\section{Cell viability assay}

MG-63 cells were seeded in 96-well plates at a density of 1 $\times 10^{3}$ cells/well in DMEM containing $10 \%$ FBS. Twenty-four hours after seeding, the medium was changed to serum-free DMEM, and the cells were incubated with various concentrations $(0-0.5 \mathrm{mg} / \mathrm{mL})$ of peptide for $24 \mathrm{~h}$. Thereafter, the medium was carefully removed, and $100 \mu \mathrm{L}$ of 3-(4,5-dimethylthiazol-2-yl)-2,5-diphenyltetrazolium bromide (MTT; $1 \mathrm{mg} / \mathrm{mL}$ final concentration) solution was added to each well prior to incubation for another $3 \mathrm{~h}$ at $37^{\circ} \mathrm{C}$ in $5 \% \mathrm{CO}_{2}$. The absorbance was then measured in a microplate reader (iMark; Bio-Rad, Hercules, CA, USA) at $540 \mathrm{~nm}$.

\section{Cell invasion assay}

For the cell invasion assay, the undersurface of the porous membranes in the Matrigel Invasion Chambers (BD Biosciences) were coated with fibronectin $(25 \mu \mathrm{g} / \mathrm{mL})$ at room temperature for $1 \mathrm{~h}$ and washed three times in DMEM. DMEM was added to the lower compartment of the chamber. Cells were cultured in DMEM without FBS overnight and treated with or without 12-O-tetradecanoylphorbol-13-acetate (TPA) $(10 \mathrm{ng} / \mathrm{mL})$ for $24 \mathrm{~h}$ in the presence or absence of $0.1 \mathrm{mg} / \mathrm{mL}$ peptide, trypsinized, and collected. Subsequently, $200 \mu \mathrm{L}$ of each cell suspension $\left(2 \times 10^{5}\right.$ cells/well in DMEM) was added to the upper compartment of the chamber and incubated at $37^{\circ} \mathrm{C}$ in a humidified atmosphere with $5 \% \mathrm{CO}_{2}$ for $24 \mathrm{~h}$. Cells on the upper surface of the membrane were removed, and cells that had migrated to the undersurface of the membrane were fixed with $3.7 \%$ formaldehyde in phosphate-buffered saline (PBS), stained with crystal violet $(0.4 \%$ dissolved in $10 \%$ ethanol) for $15 \mathrm{~min}$, washed twice with PBS, and counted under a phase-contrast microscope with a $10 \times$ objective lens. The numbers of cells in nine randomly selected fields from triplicate chambers were counted in each experiment. 

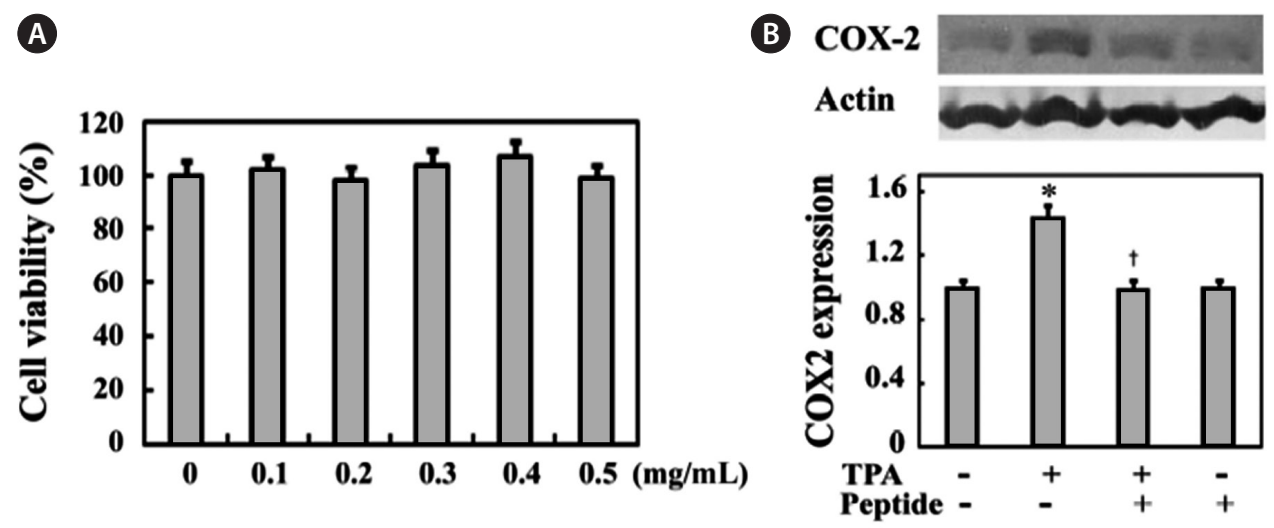

Fig. 1. Effect of anti-inflammatory peptide on the cell viability of MG-63 osteosarcoma cells. (A) MG-63 cells were treated with $0-0.5 \mathrm{mg} / \mathrm{mL}$ peptide for $24 \mathrm{~h}$ under serum-starved conditions, and their viability was determined by MTT assay. The average of the results of 3 independent experiments was used. Phosphate buffered saline-treated cells were used as a control. (B) Cells were incubated with 12-O-tetradecanoylphorbol-13-acetate (TPA, $10 \mathrm{ng} / \mathrm{mL}$ ) in the presence or absence of peptide $(0.1 \mathrm{mg} / \mathrm{mL})$ for $24 \mathrm{~h}$. Equal amounts of cell lysates were examined for cyclooxygenase 2 (COX-2) expression. Representative images are shown. Results of 3 independent experiments were averaged. " $P<0.05$ compared with control (- TPA - peptide). ${ }^{\dagger} P<0.05$ compared with TPA (+ TPA - peptide).

\section{Measurement of ROS}

DCF-DA was used to evaluate the generation of intracellular ROS. Cells $\left(3.3 \times 10^{4}\right.$ cells/well $)$ in 24 -well plates were first incubated with TPA for $24 \mathrm{~h}$ in the presence or absence of peptide. The cells were then washed with PBS and incubated with $10 \mu \mathrm{M}$ DCF-DA for $30 \mathrm{~min}$ at room temperature. Fluorescence was measured using a fluorescence plate reader.

\section{Small GTPase Rac1 activity assay}

GST-PAK-CRIB fusion protein was expressed as described previously (Miki et al., 2000) and immobilized on glutathionesepharose beads (Amersham Biosciences, Piscataway, NJ, USA). Cells were lysed in lysis buffer containing $50 \mathrm{mM}$ Tris$\mathrm{HCl}$ (pH 7.5), 10 mM MgCl $2,1 \%$ NP-40, 10\% glycerol, 200 $\mathrm{mM} \mathrm{NaCl}, 1 \mu \mathrm{g} / \mathrm{mL}$ aprotinin, $1 \mu \mathrm{g} / \mathrm{mL}$ leupeptin, $1 \mathrm{mM}$ dithiothreitol (DTT), and $1 \mathrm{mM}$ phenylmethanesulfonyl fluoride (PMSF). An aliquot of 5-10 $\mu \mathrm{L}$ of cell lysate was subjected to Western blotting. Then $1 \mathrm{~mL}$ of cell lysate was mixed with 50 $\mu \mathrm{L}$ (bed volume) of GST-PAK CRIB beads and rotated at $4{ }^{\circ} \mathrm{C}$ for $40 \mathrm{~min}$. The beads were washed three times with cold wash buffer containing $25 \mathrm{mM}$ Tris- $\mathrm{HCl}$ ( $\mathrm{pH} 7.5$ ), $30 \mathrm{mM} \mathrm{MgCl}$, $40 \mathrm{mM} \mathrm{NaCl}, 1 \% \mathrm{NP}-40,1 \mathrm{mM}$ DTT, $1 \mu \mathrm{g} / \mathrm{mL}$ aprotinin, 1 $\mu \mathrm{g} / \mathrm{mL}$ leupeptin, $1 \mathrm{mM}$ PMSF, and $20 \mu \mathrm{L}$ of sodium dodecyl sulfate (SDS) sample buffer containing $50 \mathrm{mM}$ Tris- $\mathrm{HCl}(\mathrm{pH}$ 6.8), 2\% SDS, 6\% 2-mercaptoethanol, 10\% glycerol, and 0.5 $\mathrm{mg} / \mathrm{mL}$ bromophenol blue. Samples were separated by SDSgel electrophoresis, and Rac1-GTP was detected by Western blotting.

\section{Reverse transcription-polymerization chain reac- tion (RT-PCR)}

Cells treated with TPA and/or peptide for $24 \mathrm{~h}$ were washed with ice-cold PBS twice. Total RNA was extracted using a commercial kit (RNeasy Mini Kit; Qiagen, Valencia, CA, USA) according to the manufacturer's instructions. cDNA synthesis was carried out using $3 \mu \mathrm{g}$ of total RNA. The following primers were used to determine target gene levels. MMP1 (sense 5'-GGTCTCTGAGGGTCAAGCAG-3' and antisense 5'-AGTTCATGAGCTGCAACACG-3'), MMP2 (sense 5'-ATGACAGCTGCACCACTGAG-3' and antisense 5'-ATTTGTTGCCCAGGAAAGTG-3'), COX-2 (sense 5'-TGAGCATCTACGGTTTGCTG-3' and antisense 5'-TGCTTGTCTGGAACAACTGC-3'), and GAPDH (sense 5'-GAGTCAACGGATTTGGTCGT-3' and antisense 5'-TTGATTTTGGAGGGATCTCG-3').

\section{Results}

\section{An anti-inflammatory peptide from the seahorse does not affect the viability of MG-63 osteosar- coma cells}

We first examined peptide cytotoxicity to human osteosarcoma MG-63 cells and determined the proper peptide concentration showing anti-inflammatory effects in MG-63 cells. MG-63 cells were treated with $0-0.5 \mathrm{mg} / \mathrm{mL}$ peptide for 24 h. Peptide treatment at these concentrations did not significantly inhibit cell growth (Fig. 1A). In addition, Fig. 1B shows that cell stimulation with $10 \mathrm{ng} / \mathrm{mL}$ of the pro-inflammatory agent TPA induces increased expression of cyclooxygenase- 2 (COX-2), a key enzyme that stimulates prostaglandin production, whereas $0.1 \mathrm{mg} / \mathrm{mL}$ peptide treatment effectively suppresses TPA-induced COX-2 expression. This inhibitory effect of peptide on TPA-induced COX-2 expression was not 

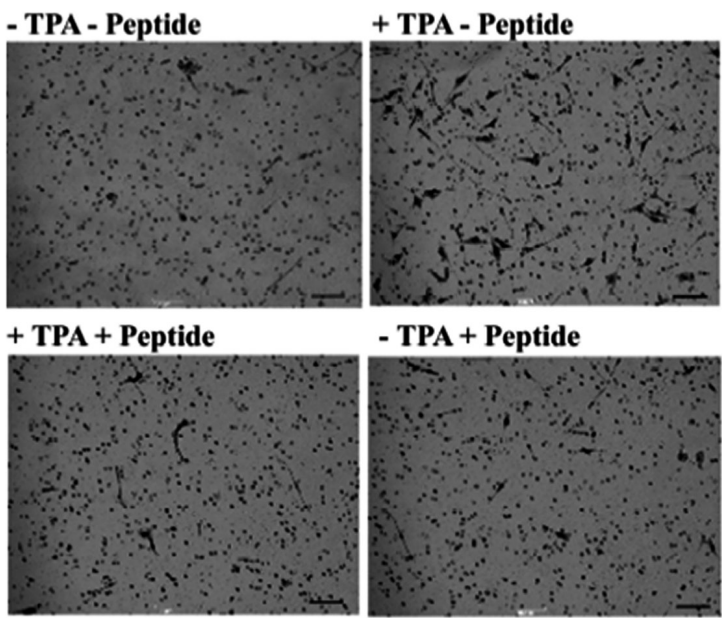

- TPA + Peptide

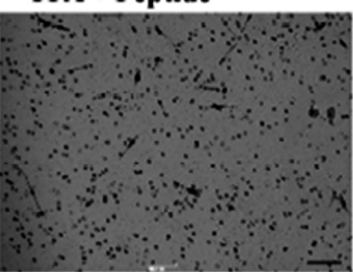

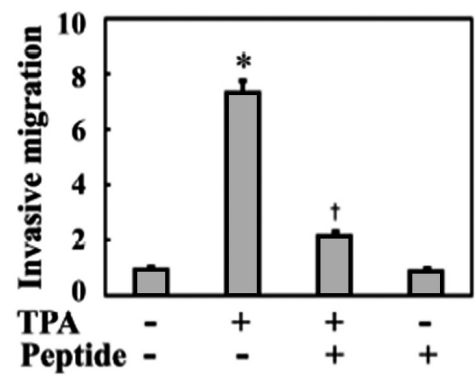

Fig. 2. Anti-inflammatory peptide from seahorse inhibits 12-0-tetradecanoylphorbol-13-acetate (TPA)-induced invasive migration of MG-63 osteosarcoma cells. Matrigel invasion assays were performed with MG-63 cells incubated with TPA $(10 \mathrm{ng} / \mathrm{mL})$ in the presence or absence of peptide $(0.1$ $\mathrm{mg} / \mathrm{mL}$ ) for $24 \mathrm{~h}$. Representative images are shown. The average of the results of 3 independent experiments was used. Phosphate buffered saline-treated cells were used as a control. " $P<0.05$ compared with control (- TPA - peptide). ${ }^{\dagger} P<0.05$ compared with TPA (+ TPA - peptide). Scale bar $=100 \mu \mathrm{m}$.

significantly altered at increased peptide concentrations (data not shown). Thus, we performed all subsequent experiments using a peptide concentration of $0.1 \mathrm{mg} / \mathrm{mL}$.

\section{Peptide inhibits TPA-induced invasive migration of MG-63 osteosarcoma cells}

Although many recent studies have shown that anti-inflammatory agents are capable of exerting antitumor activity in various tumor cells, their actual effects on the metastatic properties of osteosarcoma cells have not yet been described. Therefore, in this study, we investigated whether the antiinflammatory peptide influenced the metastatic phenotype of osteosarcoma cells, such as invasive migration. As shown in Fig. 2, TPA treatment increased the invasive migration of MG63 cells into Matrigel by approximately 7.5-fold compared to the controls, which were not treated with TPA. Treatment of MG-63 cells with $0.1 \mathrm{mg} / \mathrm{mL}$ peptide significantly inhibited TPA-induced cell invasion to approximately one-quarter of that of TPA treatment. Therefore, these results suggest that this peptide regulates an intracellular signaling cascade involved in the invasive migration of MG-63 cells.

\section{Peptide decreases TPA-induced intracellular ROS generation and Rac1 activation in MG-63 cells}

Much evidence indicates that ROS play a central role in tumor cell migration, invasion, and metastasis (Radisky et al., 2005). ROS are also well known to link inflammation to tumor promotion and metastasis. Thus, ROS generation might also be induced by TPA, which is also a well-known tumor promoter in MG-63 cells. We examined the intracellular ROS levels in MG-63 cells in the presence or absence of TPA stimulation. MG-63 cells were incubated with TPA for $24 \mathrm{~h}$ in the presence or absence of peptide. As shown in Fig. 3A, TPA treatment increased ROS levels to approximately 1.5 -fold of those seen in the controls. Comparatively, peptide treatment successfully inhibited TPA-induced ROS generation in cells.

The changes in invasive cell migration under oxidative stress also suggest the involvement of the small GTPase Rac1, which is an upstream regulator critical for actin reorganization and invasive cell migration. Rac1 is also an upstream enzyme in NADPH oxidase-dependent ROS generation (Bokoch and Knaus, 2003). Generation of ROS under a variety of physiological conditions is associated with Rac 1 activation (Werner and Werb, 2002; Nimnual et al., 2003). Therefore, we tested endogenous Rac1 activation in the presence or absence of TPA and peptide treatment via a GST-PAK binding assay using cell lysates. TPA treatment induced Rac1 activation, whereas peptide treatment decreased TPA-induced Rac1 activation (Fig. $3 \mathrm{~B})$. These data suggest that the TPA-induced Rac1-ROS cascade is involved in the invasive migration of these MG-63 cells.

\section{Peptide reduces TPA-induced expression of MMPs in MG-63 cells}

MMPs are responsible for invasive cell migration via their ECM-degrading activity. The Rac1-ROS pathway induces the expression of MMPs in a variety of cell types (Nelson and Melendez, 2004; Radisky et al., 2005). Therefore, we examined whether TPA and peptide treatment affected the expression of MMPs. MG-63 cells were stimulated with TPA for 24 $\mathrm{h}$ in the presence or absence of peptides, and then MMP ex- 


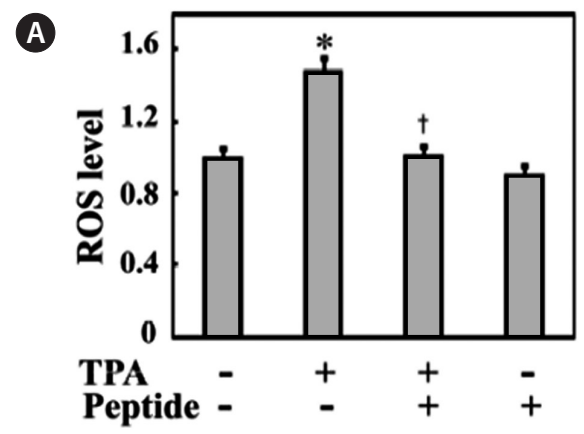

B
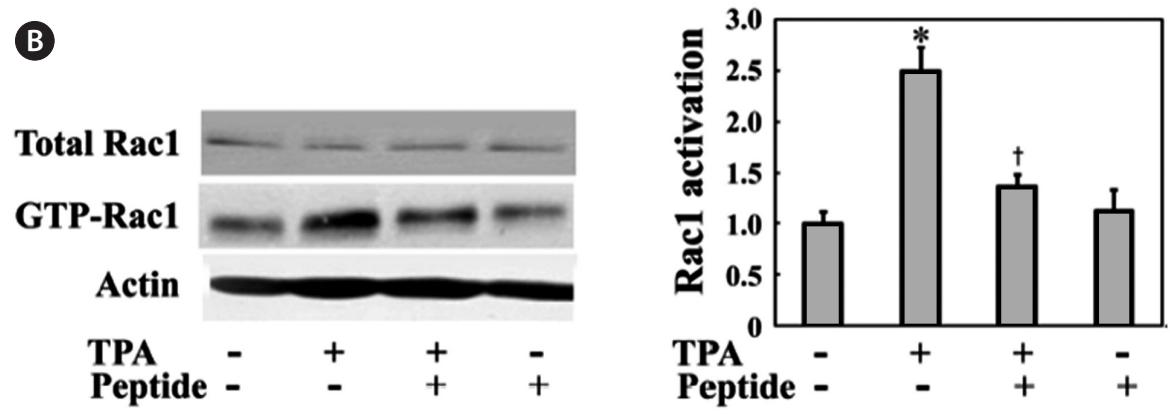

Fig. 3. Anti-inflammatory peptide attenuates 12 -O-tetradecanoylphorbol-13-acetate (TPA)-induced intracellular reactive oxygen species (ROS) generation and Rac1 activity. (A) Cells were incubated with TPA $(10 \mathrm{ng} / \mathrm{mL})$ in the presence or absence of peptide $(0.1 \mathrm{mg} / \mathrm{mL})$ for $24 \mathrm{~h}$. Cellular ROS levels were assessed by dichlorogluorescein diacetate. All data are mean \pm SD values. ${ }^{*} P<0.05$ compared with control (- TPA - peptide). ${ }^{\dagger} P<0.05$ compared with TPA (+ TPA - peptide). (B) MG-63 cells were incubated with TPA $(10 \mathrm{ng} / \mathrm{mL})$ in the presence or absence of peptide $(0.1 \mathrm{mg} / \mathrm{mL})$ for $24 \mathrm{~h}$. The purified GST-PAKPBD fusion protein was incubated with MG-63 cells lysates. The bound proteins were collected, and the GTP-bound Rac1 was detected via western blotting with anti-Rac1 antibody. The figure is representative of the results of 3 independent experiments. The average of the results of 3 independent experiments was used. Phosphate buffered saline-treated cells were used as a control. ${ }^{*} P<0.05$ compared with control (- TPA - peptide). ${ }^{\dagger} P<0.05$ compared with TPA (+ TPA - peptide).
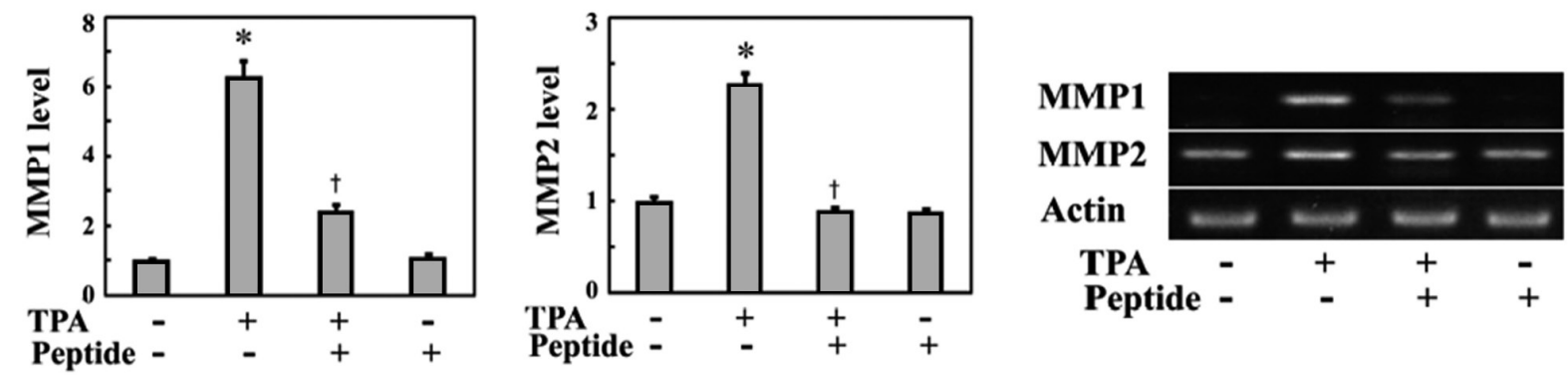

Fig. 4. Anti-inflammatory peptide attenuates mRNA expression of matrix metalloproteinase (MMP) 1 and MMP2. MG-63 cells were incubated with 12-O-tetradecanoylphorbol-13-acetate (TPA, $10 \mathrm{ng} / \mathrm{mL}$ ) in the presence or absence of peptide $(0.1 \mathrm{mg} / \mathrm{mL})$ for $24 \mathrm{~h}$. Expression of MMP1 and MMP2 was determined by real-time PCR. The average of the results of 3 independent experiments was used. ${ }^{*} P<0.05$ compared with control (-TPA - peptide). ${ }^{\dagger} P<0.05$ compared with TPA (+ TPA - peptide). PCR products after 35 cycle PCR reaction were also analyzed in $1 \%$ agarose gel.

pression was examined by mRNA quantification via RT-PCR. As shown in Fig. 4, TPA stimulation increased the expression levels of MMP1 and MMP2 mRNA in MG-63 cells, while peptide treatment inhibited the TPA-induced expression of these MMPs. In particular, MMP1 mRNA levels increased over 6.2-fold after TPA treatment and were significantly inhibited by peptide treatment. These findings suggest that the peptide suppresses invasive migration of MG-63 cells by inhibiting MMP expression through downregulating intracellular Rac1-ROS signaling.

\section{Discussion}

Osteosarcoma is an aggressive malignant bone disorder with a high potential to invade and metastasize. In the present study, we examined the effects of an anti-inflammatory and anti-oxidative agent on the metastatic invasive potential of MG-63 osteosarcoma cells. TPA stimulation increases the invasive migration of MG-63 cells, which correlates with Rac1 activation and increased intracellular ROS levels as well as increased MMP1 and MMP2 expression. In contrast, an anti- 
inflammatory peptide isolated from seahorse enzyme extracts attenuated TPA-induced intracellular ROS levels and Rac1 activation. The peptide also decreased the expression of MMP1 and MMP2. Therefore, these results suggest that the TPAinduced Rac1-ROS-linked cascade enhances invasive migration of MG-63 cells by inducing MMPs, whereas the peptide decreases invasive cell migration through downregulation of MMP expression by suppressing intracellular Rac1-ROS signals. Also, anti-inflammatory and anti-oxidative agents are able to exert substantial protective effects against osteosarcoma promotion by blocking MMP expression.

MMPs have been implicated in primary and metastatic tumor growth and angiogenesis (Nelson et al., 2000; Coussens and Werb, 2002). Selected inhibition of MMPs represents an important strategy for prevention or treatment of cancer. Some commercially available synthetic drugs such as Batimastat (BB-94) and Marimastat (BB-516) have been successfully used to lower MMP expression. However, improper metabolism, low oral bioavailability, poor solubility, side effects, and the risk of increased toxicity of synthetic drugs remain substantial challenges (Thomas and Kim, 2010). Recently, great interest has been expressed in identifying a powerful, nontoxic, and natural anti-inflammatory and anti-oxidative therapeutic agent from natural resources to prevent oxidative stress and reduce inflammatory responses and cancer metastasis. Marine resources are varied and vast, and have unique bioactivities because of the diverse environment. Thus, a marine resourcederived active peptide may be a promising, cost-effective, and safe approach to the prevention of tumor progression. Here, we successfully showed that a natural peptide from seahorse suppresses the MMP signaling response involved in invasive migration of MG-63 cells through the reduction of Rac1-mediated ROS.

The relationship between inflammation and tumor progression has been well documented, for example, recent studies showing that ROS contribute to cell migration and invasion in tumor cells. Classically, ROS were regarded as the hostdefense molecules released by neutrophils for the destruction of exogenous pathogens. Aberrant increase in intracellular ROS results in physiological and pathological changes, such as cell cycle arrest, apoptosis, and ischemia/reperfusion injury (Boonstra and Post, 2004; Otani, 2004; Gourlay and Ayscough, 2005). In fact, some compounds have been found to exert antitumor effects against osteosarcoma cells by inducing excessive ROS generation, cell growth defects, and apoptosis (Chen et al., 2012; Tian et al., 2012). However, recently, much evidence indicates that ROS generated at low concentrations play central roles in intracellular signal transduction pathways for a variety of cellular processes (Chiarugi, 2003; Aslan and Ozben, 2004; Poli et al., 2004). In particular, elevated oxidative stress has been detected in many types of cancer cells (Klaunig et al., 1998; Ambrosone, 2000), and the involvement of ROS signaling in tumor promotion and metastasis has been highlighted (Radisky et al., 2005). Consistent with these re- ports, we have shown that activated Rac1-ROS signaling in response to TPA stimulation successfully increases MMP expression and results in invasive migration of osteosarcoma MG-63 cells. This is the first report to show a possible mechanism of the antitumor effect of an anti-oxidative agent against the metastatic property of osteosarcoma cells.

We also found that treatment of MG-63 cells with Go6983, a selective protein kinase $\mathrm{C}$ (PKC) inhibitor, reduces expression of MMP1 and invasive migration of MG-63 cells (data not shown). The cellular receptor of TPA, relevant to tumor progression and metastasis, was found to be PKC (Debidda et al., 2003; Woo et al., 2004). ROS can be generated by TPA in a PKC-dependent manner (Datta et al., 2000). Therefore, the TPA/PKC-mediated signaling cascade likely cross talks with the MMP pathway to mediate TPA-induced invasive migration of MG-63 cells via ROS generation. In addition, when we compared the seahorse peptide sequences with known sequences in the translated GenBank database, the peptide sequence was found to have a high identity (>90\%) with the corresponding regions of $\alpha$-enolase from various sources. $\alpha$-Enolase is a surface receptor for plasminogen. $\alpha$-Enolasebound plasminogen promotes tumor cell invasion and cancer metastasis through conversion to plasmin and consequent ECM degradation (Pancholi and Fichetti, 1998; Vanegas et al., 2007). ROS-generating agents have been proposed to upregulate plasminogen activator (Kiguchi et al., 2001). Plasmin also induces matrix degradation via activation of MMPs. Therefore, some other invasion-related genes, such as $\alpha$-enolase and plasminogen, may also be coupled with the TPA-induced Rac1-ROS cascade to regulate MMP expression and mediate invasive migration of MG-63 cells. Additionally, the seahorse peptide is an aspartic acid-rich oligopeptide. Acidic residues are able to form ionic bonds with target molecules and also function as hydrogen bond acceptors. Many proteins that bind metal ions for structural or functional purposes possess aspartate or glutamate side chains as metal-binding sites. Therefore, identification of the direct binding targets of the peptide in MG-63 cells may help to precisely understand how the peptide exerts its antitumor effect in MG-63 cells and is an important subject for further research.

\section{Acknowledgments}

This research was supported by the Basic Science Research Program through the National Research Foundation of Korea (NRF) funded by the Ministry of Education, Science and Technology (2011-0003665) and (2011-0005476).

\section{References}

Ambrosone CB. 2000. Oxidants and antioxidants in breast cancer. Antioxid Redox Signal 2, 903-917. 
Arii S, Mise M, Harada T, Furutani M, Ishigami S, Niwano M, Mizumoto M, Fukumoto M and Imamura M. 1996. Overexpression of matrix metalloproteinase 9 gene in hepatocellular carcinoma with invasive potential. Hepatology 24, 316-322.

Aslan M and Ozben T. 2004. Reactive oxygen and nitrogen species in Alzheimer's disease. Curr Alzheimer Res 1, 111-119.

Bokoch GM and Knaus UG. 2003. NADPH oxidases: not just for leukocytes anymore!. Trends Biochem Sci 28, 502-508.

Boonstra J and Post JA. 2004. Molecular events associted with reactive oxygen species and cell cycle progression in mammalian cells. Gene 337, 1-13.

Chambers AF and Matrisian LM. 1997. Changing views of the role of matrix metalloproteinases in metastasis. J Natl Cancer Inst 89, 1260-1270.

Chen XJ, Duan FD, Zhang HH, Xiong Y and Wang J. 2012. Sodium selenite-induced apoptosis mediated by ROS attack in human osteosarcoma U2OS cells. Biol Trace Elem Res 145, 1-9.

Chiarugi P. 2003. Reactive oxygen species as mediators of cell adhesion. Ital J Biochem 52, 28-32.

Coussens LM and Werb Z. 2002. Inflammation and cancer. Nature 420, 860-867.

Datta R, Yoshinaga K, Kaneki M, Pandey P and Kufe D. 2000. Phorbol ester-induced generation of reactive oxygen species is protein kinase c $\beta$-dependent and required for SAPK activation. J Biol Chem 275, 41000-41003.

Debidda M, Sanna B, Cossu A, Posadino AM, Tadolini B, Ventura C and Pintus G. 2003. NAMI-A inhibits the PMA-induced ODC gene expression in ECV304 cells: involvement of PKC/Raf/Mek/ ERK signalling pathway. Int J Oncol 23, 477-482.

Gourlay CW and Ayscough KR. 2005. The actin cytoskeleton: a key regulator of apoptosis and ageing?. Nat Rev Mol Cell Biol 6, 583589.

Hauben EI, Arends J, Vandenbroucke JP, van Asperen CJ, Van Marck E and Hogendoorn PC. 2003. Multiple primary malignancies in osteosarcoma patients: incidence and predictive value of osteosarcoma subtype for cancer syndromes related with osteosarcoma. Eur J Hum Genet 11, 611-618.

Kähäri VM and Saarialho-Kere U. 1999. Matrix metalloproteinases and their inhibitors in tumour growth and invasion. Ann Med 31, 3445.

Kaste SC, Pratt CB, Cain AM, Jones-Wallace DJ and Rao BN. 1999. Metastases detected at the time of diagnosis of primary pediatric extremity osteosarcoma at diagnosis: imaging features. Cancer 86, 1602-1608.

Kiguchi T, Niiya K, Shibakura M, Miyazono T, Shinagawa K, Ishimaru F, Kiura K, Ikeda K, Nakata Y and Harada M. 2001. Induction of urokinase-type plasminogen activator by the anthracycline antibiotic in human RC-K8 lymphoma and H69 lung-carcinoma cells. Int J Cancer 93, 792-297.

Kim S, Choi MG, Lee HS, Lee SK, Kim SH, Kim WW, Hur SM, Kim JH, Choe JH, Nam SJ, Yang JH, Kim S, Lee JE and Kim JS. 2009. Silibinin suppresses TNF- $\alpha$-induced MMP-9 expression in gastric cancer cells through inhibition of the MAPK pathway. Molecules $14,4300-4311$.
Kimura R, Ishikawa C, Rokkaku T, Janknecht R and Mori N. 2011. Phosphorylated c-Jun and Fra-1 induce matrix metalloproteinase-1 and thereby regulate invasion activity of 143B osteosarcoma cells. Biochim Biophys Acta 1813, 1543-1553.

Klaunig JE, Xu Y, Isenberg JS, Bachowski S, Kolaja KL, Jiang J, Stevenson DE and Walborg EF Jr. 1998. The role of oxidative stress in chemical carcinogenesis. Environ Health Perspect 106 Suppl 1, 289-295.

Klein G, Vellenga E, Fraaije MW, Kamps WA and de Bont ES. 2004. The possible role of matrix metalloproteinase (MMP)-2 and MMP9 in cancer, e.g. acute leukemia. Crit Rev Oncol Hematol 50, 87100.

Liotta LA and Kohn EC. 2001. The microenvironment of the tumourhost interface. Nature 411, 375-379.

Mehta P, Lawson D, Ward MB, Lee-Ambrose L and Kimura A. 1986. Effects of thromboxane A2 inhibition on osteogenic sarcoma cellinduced platelet aggregation. Cancer Res 46, 5061-5063.

Miki H, Yamaguchi H, Suetsugu S and Takenawa T. 2000. IRSp53 is an essential intermediate between Rac and WAVE in the regulation of membrane ruffling. Nature 408, 732-735.

Mori K, Shibanuma M and Nose K. 2004. Invasive potential induced under long-term oxidative stress in mammary epithelial cells. Cancer Res 64, 7464-7472.

Nelson AR, Fingleton B, Rothenberg ML and Matrisian LM. 2000. Matrix metalloproteinases: biologic activity and clinical implications. J Clin Oncol 18, 1135-1149.

Nelson KK and Melendez JA. 2004. Mitochondrial redox control of matrix metalloproteinases. Free Radic Biol Med 37, 768-784.

Nimnual AS, Taylor LJ and Bar-Sagi D. 2003. Redox-dependent downregulation of Rho by Rac. Nat Cell Biol 5, 236-241.

Otani H. 2004. Reactive oxygen species as mediators of signal transduction in ischemic preconditioning. Antioxid Redox Signal 6, 449469.

Pancholi V and Fichetti VA. 1998. $\alpha$-Enolase, a novel strong plasmin(ogen) binding protein on the surface of pathogenic Streptococci. J Biol Chem 273, 14503-14515.

Poli G, Leonarduzzi G, Biasi F and Chiarpotto E. 2004. Oxidative stress and cell signalling. Curr Med Chem 11, 1163-1182.

Radisky DC, Levy DD, Littlepage LE, Liu H, Nelson CM, Fata JE, Leake D, Godden EL, Albertson DG, Nieto MA, Werb Z and Bissell MJ. 2005. Rac1b and reactive oxygen species mediate MMP3-induced EMT and genomic instability. Nature 436, 123-127.

Ryu B, Qian ZJ and Kim SK. 2010. SHP-1, a novel peptide isolated from seahorse inhibits collagen release through the suppression of collagenases 1 and 3, nitirc oxide products regulated by NF-kB/ p38 kinase. Peptides 31, 79-87.

Thomas NV and Kim SK. 2010. Metalloproteinase inhibitors: status and scope from marine organisms. Biochem Res Int 2010, 845975.

Thompson RC Jr, Cheng EY, Clohisy DR, Perentesis J, Manivel C and Le CT. 2002. Results of treatment for metastatic osteosarcoma with neoadjuvant chemotherapy and surgery. Clin Orthop Relat Res (397), 240-247.

Tian L, Yin D, Ren Y, Gong C, Chen A and Guo FJ. 2012. Plumbagin induces apoptosis via the p53 pathway and generation of reactive 
oxygen species in human osteosarcoma cells. Mol Med Report 5, 126-132.

Vanegas G, Quiñones W, Carrasco-López C, Concepción JL, Albericio F and Avilán L. 2007. Enolase as a plasminogen binding protein in Leishmania mexicana. Parasitol Res 101, 1511-1516.

Werner E and Werb Z. 2002. Integrins engage mitochondrial function for signal transduction by a mechanism dependent on Rho GTPases. J Cell Biol 158, 357-368.
Woo JH, Lim JH, Kim YH, Suh SI, Min DS, Chang JS, Lee YH, Park JW and Kwon TK. 2004. Resveratrol inhibits phorbol myristate acetate-induced matrix metalloproteinase- 9 expression by inhibiting JNK and PKC $\delta$ signal transduction. Oncogene 23, 1845-1853.

Zhang P, Yang Y, Zweidler-McKay PA and Hughes DP. 2008. Critical role of notch signaling in osteosarcoma invasion and metastasis. Clin Cancer Res 14, 2962-2969. 